\title{
Antibody-Mediated Status Epilepticus: A Retrospective Multicenter Survey
}

\author{
Franz Josef Holzer $^{\mathrm{a}} \quad$ Andrea O. Rossetti ${ }^{\mathrm{b}}$ Anne-Chantal Heritier-Barras ${ }^{\mathrm{a}}$ \\ Dominik Zumsteg $^{c}$ Robert Roebling ${ }^{d}$ Roman Huber $^{d}$ Holger Lerche $^{d, e}$ \\ Ines C. Kiphuth ${ }^{f}$ Jürgen Bardutzky ${ }^{f}$ Christian G. Bien ${ }^{g}$ Mathias Tröger ${ }^{h}$ \\ Gaby Schoch $^{\text {h }}$ Harald Prüssi Margitta Seeck ${ }^{\text {a }}$
}

${ }^{a}$ Department of Neurology, University Hospital, Geneva, b Department of Neurology, University Hospital, Lausanne, and 'Department of Neurology, University Hospital, Zürich, Switzerland; ' Department of Neurology, Universitätsklinikum, Ulm, e Department of Neurology and Epileptology, Hertie Institute of Clinical Brain Research, University of Tübingen, Tübingen, ${ }^{\mathrm{f}}$ Department of Neurology, University of Erlangen-Nuremberg, Erlangen, and

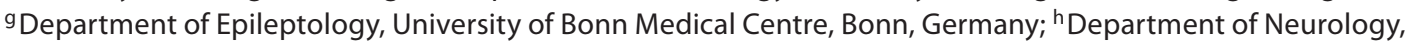
Inselspital, Bern, Switzerland; 'Department of Neurology, Charité University Medicine, Berlin, Germany

\section{Key Words}

Status epilepticus • Autoimmune encephalitis •

Antiepileptics $\cdot$ Immunomodulatory treatment $\cdot$ Patient outcome

\begin{abstract}
Background: In recent years, an increasing number of autoantibodies (AB) have been detected in the CSF and serum of patients with new onset epilepsy. Some of these patients develop convulsive or nonconvulsive status epilepticus (AB$\mathrm{SE})$, necessitating intensive medical care and administration of multiple antiepileptic and immunomodulatory treatments of uncertain effectiveness. Objectives: In this retrospective multicenter survey we aimed to determine the spectrum of gravity, the duration and the prognosis of the disorder. In addition, we sought to identify the antibodies associated with this condition, as well as determine whether there is a most effective treatment regime. Methods: $12 \mathrm{Eu}$ ropean Neurology University Clinics, with extensive experience in the treatment of SE patients, were sent a detailed
\end{abstract}

questionnaire regarding symptoms and treatment of $\mathrm{AB}-\mathrm{SE}$ patients. Seven centers responded positively, providing a total of 13 patients above the age of 16. Results: AB-SE affects mainly women $(12 / 13,92 \%)$ with a variable age at onset (1769 years, median: 25 years). The duration of the disease is also variable ( 10 days to 12 years, median: 2 months). Only the 3 oldest patients died (55-69 years). Most patients were diagnosed with anti NMDAR encephalitis (8/13) and had oligoclonal bands in the CSF (9/13). No specific treatment regimen (antiepileptic, immunomodulatory) was found to be clearly superior. Most of the surviving 10 patients (77\%) recovered completely or nearly so within 2 years of index poststatus. Conclusion: AB-SE is a severe but potentially reversible condition. Long duration does not seem to imply fatal outcome; however, age older than 50 years at time of onset appears to be a risk factor for death. There was no evidence for an optimal antiepileptic or immunomodulatory treatment. A prospective multicenter study is warranted in order to stratify the optimal treatment algorithm, determine clear risk factors of unfavorable outcome and long-term prognosis.

Copyright @ 2012 S. Karger AG, Basel

\section{KARGER}

Fax +4161306 1234

E-Mail karger@karger.ch

www.karger.com (c) 2012 S. Karger AG, Basel

$0014-3022 / 12 / 0685-0310 \$ 38.00 / 0$

Accessible online at:

www.karger.com/ene
Dr. Franz Josef Holzer

University Hospital of Geneva, Department of Neurology, Unité d'Epileptologie clinique, ElectroEncéphaloGraphie et Evaluation préchirurgicale de l'épilepsie

4, rue Gabrielle-Perret-Gentil, CH-1211 Genève 14 (Switzerland)

E-Mail franz-josef.holzer@hcuge.ch 


\section{Introduction}

In the last few years, an increasing number of autoantibodies has been detected in patients with new onset epilepsy, leading to the concept of a subgroup of epilepsy as an autoimmune disease [1-3]. Some antibodies (AB) like those directed to glutamic acid decarboxylase (GAD$\mathrm{AB}$, associated with stiff-person syndrome and epilepsy) seem to be of autoimmune origin, others like anti-Hu of paraneoplastic, whereas NMDAR-AB can be of either origin [4]. It is hypothesized that some of these antibodies modulate the equilibrium between excitatory and inhibitory mechanisms in the central nervous system, either by targeting ion channels (e.g. antibodies against $\mathrm{N}$-methyl-D-aspartate receptor; NMDAR-AB [5]) or key enzymes (e.g. antibodies against GAD, the enzyme which converts glutamic acid into gamma aminobutyric acid [6]), leading to a gain of excitability or a lack of inhibition and consequently resulting in seizures, among other symptoms.

Some of these patients with $\mathrm{AB}$ develop status epilepticus (AB-SE) [7], convulsive or nonconvulsive, and require prolonged intensive care, mechanical ventilation and multiple antiepileptic and immunomodulatory treatments $[8,9]$. To date, there are no good data about the ultimate outcome of these patients. There is also sparse knowledge about the most effective treatments. It is therefore important to comprehensively investigate the clinical characteristics and course of AB-SE and whether there is a uniquely successful treatment regimen.

\section{Methods}

We sent a detailed questionnaire to 12 European Neurology University Clinics, with extensive experience in the treatment of SE. The study was limited to patients older than 16 years. Seven centers responded positively (Berne, Lausanne, Zurich, Berlin, Bonn, Erlangen, Ulm), providing a total of 13 patients, including our 2 patients (Geneva), diagnosed with AB-SE between 2003 and 2011.

We inquired about patient characteristics, clinical features, history of neoplasia or autoimmune disease, duration of SE (table 1), antibodies and paraclinical findings including imaging, results of CSF and ictal and interictal EEG (table 2) and administered treatments and outcome (table 3 ).

There is no universally accepted definition of nonconvulsive status epilepticus (NCSE); however, all our patients showed abnormal, focal, or multifocal or generalized rhythmic activity, with evolution in frequency, morphology and field (except in 1 patient where judgment was based purely on the clinical picture).

\section{Results}

\section{Clinical Findings}

Patients were aged from 17 to 69 years; the mean age was 32.5 years ( $17-69$ years, median 25 years). There was a high female-male ratio $(12 / 13 ; 92 \%)$.

One patient presented prodromal, unspecific symptoms, such as fatigue or headache before the occurrence of status epilepticus (SE), neuropsychiatric symptoms including behavioral changes, memory loss, agitation and psychosis, or isolated simple, complex partial or generalized epileptic seizures were found in 12 patients. Altogether, 12 of 13 had more or less significant clinical symptoms before AB-SE occurred.

When hospitalized for SE, 3 patients were found to have an underlying neoplastic disease (23\%: 2 ovarian teratoma and 1 small cell lung cancer); whereas in 2 other patients an ovarian teratoma was diagnosed only later, i.e. 1 and 2 years, respectively, after complete recovery (total of patients with tumor 38\%). One patient suffered from steroid-responsive encephalitis associated with thyroiditis (Hashimoto).

The latencies between the first symptoms and the onset of status epilepticus varied from 0 to 11 months. In 7/13 patients (53\%), SE was present within the first week of symptoms. In the other half (47\%), the delay between onset and SE was between 1 week and 11 months (mean 3.3 months, median 1 month).

Duration of SE varied considerably from $2 \mathrm{~h}$ to 12 years, in 3 cases less than a month ( 2 h, 10 and 18 days, respectively), in 1 case 12 years (patient 5), but in the majority (9 of 13) SE lasted between 1 and 4 months. Nine patients needed pharmacological coma induction and mechanical ventilation, independently of duration or type of $\mathrm{AB}$.

The majority of our patients (70\%) had either complex partial (7/13), or generalized tonic-clonic seizures (5/13). Only 1 patient presented with simple partial seizures.

\section{Paraclinical Findings}

Serum

Serum antibodies against NMDA receptor were most frequently associated with SE, found in 8 of 13 patients (61\%; patients 1, 2, 5, 7, 8, 9, 10 and 12). Except in patient 8 , where it was not specifically tested, all patients with these serum antibodies also had NMDAR-AB in the cerebrospinal fluid.

Antibodies against GAD were found in 1 patient (No. 11, also positive in the CSF), and against hippocampal neuropil without further specification of the reactivity 
Table 1. Patients and clinical features

\begin{tabular}{|c|c|c|c|c|c|c|c|c|c|}
\hline $\begin{array}{l}\mathrm{Pa}- \\
\text { tient } \\
\text { No. }\end{array}$ & $\begin{array}{l}\text { Refer- } \\
\text { ence } \\
\text { center }\end{array}$ & $\begin{array}{l}\text { Gen- } \\
\text { der }\end{array}$ & $\begin{array}{l}\text { Age at } \\
\text { onset } \\
\text { years }\end{array}$ & First symptoms & $\begin{array}{l}\text { Neoplasia or } \\
\text { other diseases }\end{array}$ & $\begin{array}{l}\text { Beginning of } \\
\text { epilepsy after } \\
\text { onset of first } \\
\text { symptoms }\end{array}$ & $\begin{array}{l}\text { Type of } \\
\text { epilepsy }\end{array}$ & $\begin{array}{l}\text { Duration } \\
\text { of status } \\
\text { epilepticus }\end{array}$ & $\begin{array}{l}\text { Intuba- } \\
\text { tion }\end{array}$ \\
\hline 1 & Geneva & M & 58 & $\begin{array}{l}\text { headache, disinhibition, } \\
\text { aggressivity, short term } \\
\text { memory loss }\end{array}$ & none & 6 months & $\begin{array}{l}\text { facial and upper } \\
\text { limbs myoclonus } \\
(\mathrm{CP})\end{array}$ & 4 months & yes \\
\hline 2 & Geneva & $\mathrm{F}$ & 22 & $\begin{array}{l}\text { dizziness, disorientation, } \\
\text { amnesia, agitation, } \\
\text { epileptic seizure }\end{array}$ & $\begin{array}{l}\text { ovarian teratoma } \\
\text { discovered } 1 \text { year } \\
\text { after full recovery }\end{array}$ & 1 week & NCSE & 2 months & yes \\
\hline 3 & Berne & $\mathrm{F}$ & 55 & $\begin{array}{l}\text { loss of energy, } \\
\text { restlessness, short term } \\
\text { memory loss }\end{array}$ & none & 11 months & GTCS & 10 days & yes \\
\hline 4 & Lausanne & $\mathrm{F}$ & 69 & $\begin{array}{l}\text { generalized clonic and } \\
\text { CP seizures, progressive } \\
\text { obtundation }\end{array}$ & $\begin{array}{l}\text { small cell lung } \\
\text { cancer }\end{array}$ & 0 months & $\begin{array}{l}\text { GC and } \mathrm{CP} \\
\text { seizures }\end{array}$ & $\begin{array}{l}26 \text { days } \\
\text { ( } 1 \text { month })\end{array}$ & yes \\
\hline 5 & Lausanne & $\mathrm{F}$ & 25 & $\begin{array}{l}\text { fatigue, somnolence, } \\
\text { dysphasia }\end{array}$ & none & 3 weeks & $\begin{array}{l}\text { GC and CP } \\
\text { seizures }\end{array}$ & 3 months & no \\
\hline 6 & Lausanne & $\mathrm{F}$ & 28 & SP seizures & none & 0 months & SP seizures & 12 years & yes \\
\hline 7 & Zurich & $\mathrm{F}$ & 37 & $\begin{array}{l}\text { psychosis, disorientation, } \\
\text { agitation, dysphagia, } \\
\text { dysarthria }\end{array}$ & ovarian teratoma & 0 months & NCSE & 4 months & yes \\
\hline 8 & Zurich & $\mathrm{F}$ & 36 & $\begin{array}{l}\text { psychosis, depression, } \\
\text { insomnia, dyslexia }\end{array}$ & none & 0 months & NCSE & 4 months & yes \\
\hline 9 & Berlin & $\mathrm{F}$ & 19 & $\begin{array}{l}\text { headache, epileptic } \\
\text { seizure, disorientation, } \\
\text { anxiety, irritability }\end{array}$ & ovarian teratoma & 0 months & GTCS & $2 \mathrm{~h}$ & no \\
\hline 10 & Bonn & $\mathrm{F}$ & 17 & GTCS & none & 0 months & GTCS & 18 days & no \\
\hline 11 & Erlangen & $\mathrm{F}$ & 21 & dystonia & Hashimoto & 1 month & CP seizures & $\begin{array}{l}2 \text { and } \\
3 \text { months }\end{array}$ & yes \\
\hline 12 & Ulm & $\mathrm{F}$ & 17 & $\begin{array}{l}\text { psychosis, agitation, } \\
\text { seizures, amnesia }\end{array}$ & none & 1 month & GTCS & 5 weeks & yes \\
\hline 13 & Ulm & $\mathrm{F}$ & 19 & $\begin{array}{l}\text { psychosis, agitation, } \\
\text { seizures, amnesia, } \\
\text { incontinence, mild } \\
\text { dyskinesia }\end{array}$ & $\begin{array}{l}\text { ovarian teratoma } \\
\text { discovered } 2 \text { years } \\
\text { after full recovery }\end{array}$ & 0 months & GTCS & $\begin{array}{l}\text { intermittent } \\
\text { for a few } \\
\text { weeks }\end{array}$ & no \\
\hline
\end{tabular}

NCSE = Nonconvulsive status epilepticus; GTCS = generalized tonic-clonic seizures; GC = generalized clonic; CP = complex partial; SP = simple partial.

(negative for all known antigenic specificities, No. 13) in another patient, whereas in 2 patients (Nos. 3 and 6) the testing for any of these serum antibodies was negative. However, in these 2 patients, oligoclonal bands in the CSF indicated autoimmune origin. Patient 6 had none of these serum antibodies, but antibodies against GluR3 in the CSF were present. In patient $4 \mathrm{Ri}-\mathrm{AB}$ was found in the serum, but not in the CSF.

\section{Cerebrospinal Fluid}

Oligoclonal bands were found in 9/13 patients (69\%), including NMDAR-AB and non-NMDAR-AB patients. White blood cell counts (WBC) were also elevated in most patients (in 11 of 13 patients; 85\%), ranging from 6 to 134 million/l. Only patient 6 with anti-GluR3 and patient 11 with GAD-AB had normal WBC. Abnormally elevated CSF protein levels were found in 4 patients (30\%), 
Table 2. Antibodies and paraclinical findings

\begin{tabular}{|c|c|c|c|c|c|c|c|}
\hline $\begin{array}{l}\mathrm{Pa}- \\
\text { tient } \\
\text { No. }\end{array}$ & $A B$ in serum & $\mathrm{AB}$ in $\mathrm{CSF}$ & Brain MRI & FDG-PET & CSF & Interictal EEG & Ictal EEG \\
\hline 3 & no $\mathrm{AB}$ detected & $\begin{array}{l}\text { no } A B \\
\text { detected }\end{array}$ & $\begin{array}{l}\text { normal, then } \mathrm{T}_{2} \\
\text { hyperintensity in } \\
\text { bilateral hippocampus }\end{array}$ & & $\begin{array}{l}\text { WBC: } 15 ; \\
\text { prot: } 1.6 \mathrm{~g} / \mathrm{l} ; \\
\text { OB: positive } \\
\text { (type 2) }\end{array}$ & $\begin{array}{l}\text { severe general } \\
\text { slowing }\end{array}$ & $\begin{array}{l}\text { continuous frontal sharp } \\
\text { slow waves }\end{array}$ \\
\hline 5 & NMDAR-AB & NMDAR-AB & $\begin{array}{l}\text { normal, then minimal } \\
\text { diffuse atrophy }\end{array}$ & & $\begin{array}{l}\text { WBC: } 27 \\
\text { prot: } 0.37 \mathrm{~g} / \mathrm{l} ; \\
\text { OB: positive }\end{array}$ & $\begin{array}{l}\text { diffuse theta-delta } \\
\text { slowing }\end{array}$ & $\begin{array}{l}\text { rhythmic anterior delta, } \\
\text { waxing and waning }\end{array}$ \\
\hline 6 & 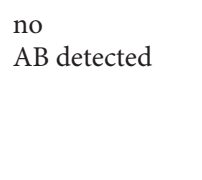 & anti-GLUR3 & $\begin{array}{l}\text { progressive, focal right } \\
\text { parietal atrophy }\end{array}$ & $\begin{array}{l}\text { striatal } \\
\text { hypermetabolism }\end{array}$ & normal, no OB & $\begin{array}{l}\text { right hemispheric } \\
\text { spikes, multifocal, } \\
\text { on a moderately } \\
\text { slow background } \\
\mathrm{R}>\mathrm{L}\end{array}$ & $\begin{array}{l}\text { right hemispheric spikes, } \\
\text { multifocal, on a } \\
\text { moderately slow } \\
\text { background } \mathrm{R}>\mathrm{L}\end{array}$ \\
\hline 7 & NMDAR-AB & NMDAR-AB & $\begin{array}{l}\text { normal (DVA frontal } \\
\text { sup. gyrus) }\end{array}$ & $\begin{array}{l}\text { bifrontal and } \\
\text { bithalamic } \\
\text { hypermetabolism }\end{array}$ & $\begin{array}{l}\text { WBC: } 37 ; \\
\text { prot: } 0.48 \mathrm{~g} / \mathrm{l} ; \\
\text { OB: positive }\end{array}$ & $\begin{array}{l}\text { continuous } \\
\text { monomorph delta, } \\
\text { areactive }\end{array}$ & $\begin{array}{l}\text { multifocal NCSE, } \\
\text { initially bitemporal } \\
\text { independent, later } \\
\text { bifrontal }\end{array}$ \\
\hline 10 & NMDAR-AB & NMDAR-AB & $\begin{array}{l}\text { status related, later on } \\
\text { regressive bilateral } \\
\text { cortical signal increase }\end{array}$ & & $\begin{array}{l}\text { WBC: } 40 ; \\
\text { prot: } 0.31 \mathrm{~g} / \mathrm{l} ; \\
\text { OB: positive }\end{array}$ & $\begin{array}{l}\text { diffuse theta } \\
\text { slowing }\end{array}$ & right hemispheric status \\
\hline 11 & $\mathrm{GAD}-\mathrm{AB}$ & anti-GAD & $\begin{array}{l}\text { initially normal, then } \\
\text { bitemporal } \\
\text { hyperintensive lesion }\end{array}$ & & $\begin{array}{l}\text { WBC: } 2 \text {; } \\
\text { prot: normal, } \\
\text { lactate: } 2.2 \mathrm{mmol} / 1\end{array}$ & alpha EEG & theta, ETPs \\
\hline 12 & NMDAR-AB & NMDAR-AB & normal, repeatedly & & $\begin{array}{l}\text { WBC: } 80 \text {; } \\
\text { OB: negative } \\
\text { all else negative }\end{array}$ & $\begin{array}{l}\text { irregular theta to } \\
\text { delta, no ETPs }\end{array}$ & bifrontal and generalized \\
\hline 13 & $\begin{array}{l}\text { unclassified } \mathrm{AB} \\
\text { against hippo- } \\
\text { campal neuropil }\end{array}$ & not done & normal, repeatedly & & $\begin{array}{l}\text { WBC: } 40 \text {; } \\
\text { OB: negative } \\
\text { all else negative }\end{array}$ & $\begin{array}{l}\text { irregular theta to } \\
\text { delta, no ETPs }\end{array}$ & bifrontal and generalized \\
\hline
\end{tabular}

GLUR3-AB = Antiglutamate receptor 3-AB; GAD-AB = glutamic acid decarboxylase- $\mathrm{AB}$; $\mathrm{Ri}-\mathrm{AB}=$ antineuronal nuclear autoantibody type 2-AB (i.e. ANNA-2); DVA = developmental venous anomaly; ETPs = epilepsy-typical potentials; $\mathrm{OB}=$ oligoclonal bands; $\mathrm{WBC}=$ white blood cells $($ normal: $0-3$ ). 
Table 3. Treatments and outcome

\begin{tabular}{|c|c|c|c|c|c|c|c|c|}
\hline $\begin{array}{l}\mathrm{Pa}- \\
\text { tient } \\
\text { No. }\end{array}$ & Inefficient AED & Efficient AED & $\begin{array}{l}\text { Steroids } \\
\text { i.v. }\end{array}$ & PE & IvIg & CPM & RTM & Outcome \\
\hline 2 & $\mathrm{LEV}+\mathrm{VPA}+\mathrm{CLP}+\mathrm{PRO}$ & none & + & + & + & - & + & $\begin{array}{l}\text { nearly restitutio ad } \\
\text { integrum (mild dysexe- } \\
\text { cutive disorders) }\end{array}$ \\
\hline 3 & LEV, LTG, VPA & none & - & - & - & - & - & death \\
\hline 4 & CLZ, LEV, LZP, PHT, TPM, THP & none & + & - & - & - & - & death \\
\hline 5 & $\begin{array}{l}\text { LEV, CBZ, LZP, TPM, THP, } \\
\text { MDZ, KTM, LCS }\end{array}$ & $\mathrm{PRO}+\mathrm{PB}+\mathrm{PGB}+\mathrm{PHT}$ & + & + & + & - & - & $\begin{array}{l}\text { nearly restitutio ad } \\
\text { integrum (mild memory } \\
\text { dysfunction) }\end{array}$ \\
\hline 8 & $\begin{array}{l}\text { VPA, LZP, MDZ, PRO, PHT, PB, } \\
\text { CLB, TPM, LEV, THP, FBM }\end{array}$ & none & + & + & + & + & - & $\begin{array}{l}\text { severe deficits } \\
\text { (cognitive, physical, } \\
\text { remains dependent) }\end{array}$ \\
\hline 9 & LEV, DZP & $\mathrm{LZP}+\mathrm{PRM}$ & + & - & - & - & - & restitutio ad integrum \\
\hline 10 & $\mathrm{PHT}+\mathrm{LEV}, \mathrm{VPA}+\mathrm{CLB}$ & $\mathrm{GBP}+\mathrm{PB}+\mathrm{PHT}+\mathrm{VPA}$ & + & - & - & - & - & $\begin{array}{l}\text { nearly restitutio ad } \\
\text { integrum }\end{array}$ \\
\hline 11 & PHT, VPA & $\begin{array}{l}\mathrm{CLP}+\mathrm{GBP}+\mathrm{LEV}+ \\
\mathrm{LZP}+\mathrm{PRM}\end{array}$ & - & + & + & + & - & $\begin{array}{l}\text { hearing impairment, no } \\
\text { cognitive deficits }\end{array}$ \\
\hline
\end{tabular}

$\mathrm{CBZ}=$ Carbamazepine; $\mathrm{CLB}=$ clobazam; CLP = clonazepam; $\mathrm{CLZ}=$ clorazepate; $\mathrm{DZP}=$ diazepam; $\mathrm{FBM}=$ felbamate; $\mathrm{GBP}=$ gabapentine; $\mathrm{KTM}=$ ketamine; $\mathrm{LTG}=$ lamotrigine; $\mathrm{LEV}=$ levetiracetam; $\mathrm{LCS}=$ lacosamide; $\mathrm{LZP}=$ lorazepam; $\mathrm{MDZ}=$ midazolam; $\mathrm{PB}=$ phenobarbital; $\mathrm{PHT}=$ phenytoin $\mathrm{PGB}=$ pregabaline;
$\mathrm{PRM}=$ primidone; $\mathrm{PRO}=$ propofol; $\mathrm{THP}=$ thiopental; $\mathrm{TPM}=$ topiramate; $\mathrm{VGV}=$ vigabatrin; $\mathrm{VPA}=$ valproic acid; $\mathrm{PE}=$ plasmapheresis; IvIg = intravenous immunoglobulin; $\mathrm{CPM}=$ cyclophosphamide; RTM = rituximab; VNS = vagus nerve stimulation. independent of the type of AB. Overall, 4 patients had no oligoclonal bands (Nos. 6, 11, 12 and 13).

\section{EEG}

Interictal EEG findings generally showed theta or delta slowing (12 of 13 patients). Only patient 11 with GAD$\mathrm{AB}$ had a normal interictal EEG. Given that patients were in SE, ictal recordings were obtained in all but 1 patient (No. 9). In this patient (NMDAR-AB), no ictal EEG was obtained due to the short duration of SE. In the remain- ing, ictal EEG revealed frontal or fronto-temporal seizure onset in 7 patients (54\%, Nos. 1, 3, 5, 6, 10, 12 and 13), multifocal in 1 (No.4), and nonconvulsive epileptic status in 3 patients (Nos. 2, 7 and 8, all NMDAR-AB). Patient 11 (GAD-AB) showed generalized slowing with epileptiform discharges (fig. 1).

\section{Brain Imaging}

MRI was initially normal in 10 patients (77\%), and remained normal in 5 (patients 2, 7, 8, 12 and 13). Cortical, 
hippocampal and temporal signal increase was found in 4 (patients 3, 9, 10 and 11). Patients 1 and 5 with initially normal MRI showed subsequently diffuse atrophy. In patient 6 with GluR3-AB, a focal right parietal atrophy appeared after 2 years (histologically confirmed adult Rasmussen encephalitis, recently reported [10]).

Cerebral FDG-PET scan was done in 4 patients (all with NMDAR-AB) and showed in patient 1 severe bilateral parietotemporo-occipital and basal ganglia hypometabolism, in patient 6 striatal hypermetabolism correlating with disease course (recently reported [11]), in patient 7 bifrontal and bithalamic hypermetabolism, whereas in patient 8 bilateral hypometabolism spared the subcortical regions and was present in the occipital and motor cortex regions.

\section{Treatments and Response}

Classic antiepileptic and new-generation antiepileptic drugs (AED) individually or in combination have been used to control AB-SE, but with poor results. Phenytoin, valproic acid and levetiracetam or their combination have consistently failed, despite dosages and serum levels in the recommended therapeutic range. In 7 patients (54\%) there was no efficient AED at all, whereas 1 patient (No. 9) responded to lorazepam and primidone, 3 patients improved with a combination of 4 AED (Nos. 5, 6 and 10), and 1 (No. 11) with 5 AED.

Of the 8 patients who recovered completely or nearly completely, 3 of them (Nos. 9, 10 and 12, all NMDAR-AB) received steroids as the unique immunomodulatory treatment. Patient 5 (NMDAR-AB) responded with some delay to a combination of steroids, plasma exchange (PE) and IvIg, or possibly spontaneously, patient 7 (NMDAR$\mathrm{AB}$ ) to steroids and IvIg, whereas patient 13 (AB hippocampal neuropil) improved without any immunomodulatory treatment. Patient 6 (GluR3-AB) received steroids early in her illness, but improved somewhat only after VNS was implanted several years later. Patient 8 (NMDAR-AB) responded to steroids, PE, IvIg and cyclophosphamide. Patient 11 (GAD-AB) did not receive steroids but transiently improved after PE and IvIg, and finally recovered after cyclophosphamide.

\section{Outcome}

Eight patients of $13(62 \%)$ recovered completely or nearly completely (Nos. 2, 5, 7 and 9-13), despite a mean duration of SE of 50 days (patient 11 remained with a hearing impairment but no other neurological or cognitive deficits). Only 2 of the 10 surviving patients remained severely disabled (patients 8 and 6 with adult Rasmussen

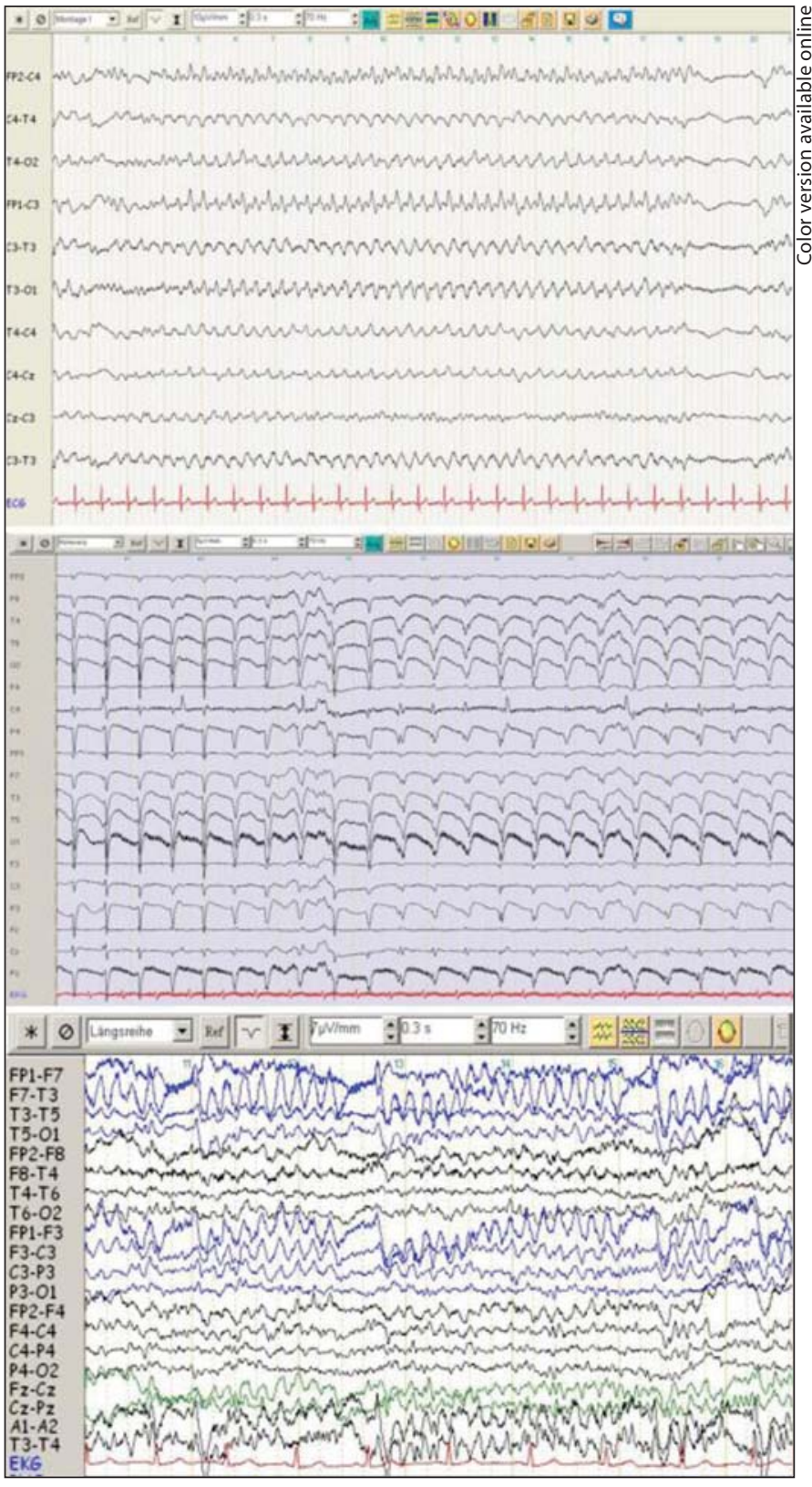

Fig. 1. EEG samples of SE of patients 1 (NMDAR-AB), 11 (GAD$\mathrm{AB}$ ), and 13 (unclassified antibody), from top to bottom.

encephalitis, but stabilized in his course). Recovery may be long and in some patients took more than 1-2 years (Nos. 12 and 13). Two patients are of special interest: patient 2 recovered after AED (with no response) and after immunomodulatory therapy; however, with persisting NMDAR-AB, an ovarian teratoma was found and operated only 1 year after full recovery. Patient 13, without any immunomodulatory treatment and without any re- 
sponse to AED; this young female recovered spontaneously and completely over 1 year, but an ovarian teratoma was discovered and removed only 2 years later.

Three patients died. Patient 1 (NMDAR-AB) died after several months of SE despite five different immunomodulatory treatments and without an underlying tumor disease. Patient 3, with no specific $A B$ detected probably died from brain edema and autonomic dysfunction and the course was fulminant (10 days). Patient 4 died 26 days after onset (Ri-AB and small cell lung cancer) during SE.

\section{Discussion}

$\mathrm{AB}-\mathrm{SE}$ is a rare, heterogeneous condition, and diagnosed on the basis of clinical features of encephalitis, EEG changes and laboratory results, requiring care in intensive care units (ICU). In our retrospective multicenter survey of 13 patients, we identified as potential risk factors female gender (12 of 13) and serum NMDAR-AB (8 of 13). The prevalence of autoimmune diseases in women is well known and possible explanations are provided in a recent review [12] (e.g. higher CD4+ lymphocytes, enhanced cytokine production in the presence of estrogen).

Pathophysiological mechanisms of epilepsy of autoimmune origin, or its most extreme form AB-SE, are not perfectly understood. In particular, it remains unclear as to whether the antibodies are pathogenic themselves or simply a marker of another directly pathogenic process. In any case, the treating physician aims to shorten that process by introducing immunomodulatory treatment.

In our patient group, there is no evidence for the best first-line treatment. Despite attempts to treat with various antiepileptic medications of different and complementary pharmacological characteristics, inconclusive outcomes have resulted with no evidence for a one most effective antiepileptic drug or combination therapy.

No straightforward picture emerged either regarding the immunomodulatory treatments. Ten patients received steroids, which did not help in 5/10. Interestingly, $\mathrm{PE}$ and IvIg were given in less than $50 \%$ of the patients, despite a long SE duration in some of them (e.g. patients 4,12 and 13). This may indicate a delayed referral to neurologists or immunologists and/or limited awareness of AB-SE within the ICU staff, delaying reinforcement of therapy. Overall, our study cannot confirm or invalidate the hypothesis that early and aggressive immunomodulatory treatment (e.g. steroids, PE, IvIg, or their association) would change the course of the disease.
As shown in previous studies $[13,14]$, the removal of an underlying tumor, if possible, is related to better outcome. However, this view is challenged by our observation. The condition of 2 patients recovered completely before the tumor was detected, indicating that even in a probable paraneoplastic context, conservative treatment may be sufficient.

$\mathrm{AB}-\mathrm{SE}$ is a serious condition with high mortality (3 of $13,23 \%)$. Interestingly, all the patients who died were also the oldest of our series $(55,58$ and 69 years old). While a paraneoplastic origin was found in one of them, there was no evidence of an underlying tumor in the other 2 patients. DeLorenzo et al. [15] noted in 1996 that the 'The prognosis of SE in adults is poorer than in children and particularly so in those over 60 years of age'. This difference was thought to be due to the underlying pathology. In the DeLorenzo data most of the older subjects suffered from brain anoxia or (larger) acute stroke, i.e. a pathology that is per se related to a poorer prognosis. However, several other papers underscore that age and etiology are the most important independent outcome predictors in SE [16]. It remains to be shown in further studies whether age will emerge as an independent risk factor in AB-SE or if other factors, such as less aggressive therapy in older patients, determine this unfavorable outcome.

ABs to intracellular antigens may be associated with bad response to immunomodulatory treatment and poorer outcome, whereas ABs to extracellular antigens are believed to have a better prognosis. Our case series does not confirm this hypothesis. Of our 3 patients with a fatal outcome, only 1 had $\mathrm{AB}$ against an intracellular antigen (patient $4, \mathrm{Ri}-\mathrm{AB}$ ), while another had $\mathrm{AB}$ against an extracellular antigen (patient 1, NMDAR-AB), and in 1 patient there was no known $\mathrm{AB}$ at all. Furthermore, 1 patient with a good outcome (patient 11) had an $A B$ against intracellular antigen (GAD-AB).

In a recent study on 7 ICU patients with NMDAR-AB [17], with an age range from 19 to 31, the outcome was favorable in all of them. Another 6 ICU patients with NMDAR-AB and encephalitis, with an age range from 20 to 41 , were reported in a recent cohort study [18]. Half of them had a slow but good recovery, 2 were left with severe neurological deficits and 1 , the oldest of the cohort, succumbed to pneumonia 6 months after onset. Thus the outcome remains variable and unpredictable, even if the type of $\mathrm{AB}$ and the age range are comparable.

It is of note that most patients survived and $62 \%(8 / 13)$ with good-to-excellent neurological and cognitive outcome, although recovery in some cases took up to two years. Outcome was independent of the duration of sta- 
tus, i.e. even with $\mathrm{AB}-\mathrm{SE}$ of several months, there was a good chance for full or almost full recovery. This is exemplified by patients 5 and 7, who were in SE for 3 and 4 months, respectively, but eventually recovered almost completely. This is an important observation, given the recurrent discussions with ICU staff that arise regarding how long these patients should remain on life support and whether they will recover.

Despite the recent sharp increase in the description of autoimmune epilepsy and AB-SE in the literature, there is still no established algorithm of treatment strategy. Prospective multicenter studies are needed to determine optimal treatment, and whether early and aggressive immunomodulatory therapy prevents fatal outcome and/or shortens significantly the ICU stay. An additional point to consider is also that early treatment requires fast laboratory confirmation of relevant $\mathrm{AB}$ in high titers. Furthermore, increased awareness of this often reversible condition (SE of unclear origin, with a history of neuropsychiatric or infectious symptoms) is mandatory to shorten the delay to proper diagnosis and treatment.

\section{Acknowledgements}

Supported by a grant from the Swiss National Science Foundation: SPUM 33CM30-140332.

\section{References}

1 Palace J, Lang B: Epilepsy: an autoimmune disease? J Neurol Neurosurg Psychiatry 2000;69:711-714

2 McKnight K, Jiang Y, Hart Y, et al: Serum antibodies in epilepsy and seizure-associated disorders. Neurology 2005;65:1730-1736.

3 Vincent A, Irani SR, Lang B: The growing recognition of immunotherapy-responsive seizure disorders with autoantibodies to specific neuronal proteins. Curr Opin Neurol 2010;23:144-150.

4 Dalmau J: Status epilepticus due to paraneoplastic and nonparaneoplastic encephalitides. Epilepsia 2009;50(suppl 12):58-60.

5 Hughes EG, Peng X, Gleichman AJ, Lai M, Zhou L, Tsou R, et al: Cellular and synaptic mechanisms of anti-NMDA receptor encephalitis. J Neurosci 2010;30:5866-5875.

6 Manto MU, Laute MA, Aguera M, Rogemond V, Pandolfo M, Honnorat J: Effects of anti-glutamic acid decarboxylase antibodies associated with neurological diseases. Ann Neurol 2007;61:544-551.

7 Nociti V: Refractory generalized seizures and cerebellar ataxia associated with antiGAD antibodies responsive to immunosuppressive treatment. Eur J Neurol 2010;17:e5.
8 Kanter IC, Huttner HB, Staykov D, Biermann T, Struffert T, Kerling F, et al: Cyclophosphamide for anti-GAD antibody-positive refractory status epilepticus. Epilepsia 2008;49:914-920.

9 Suleiman J, Brenner T, Gill D, Brilot F, Antony J, Vincent A, et al: VGKC antibodies in pediatric encephalitis presenting with status epilepticus. Neurology 2011;76:1252-1255.

10 Grujic J, Bien CG, Pollo C, Rossetti AO: Vagus nerve stimulator treatment in adult-onset Rasmussen's encephalitis. Epilepsy Behav 2011;20:123-125.

11 Maeder-Ingvar M, Prior JO, Irani SR, Rey V, Vincent A, Rossetti AO: FDG-PET hyperactivity in basal ganglia correlating with clinical course in anti-NDMA-R antibodies encephalitis. J Neurol Neurosurg Psychiatry 2011;82:235-6.

12 Voskuhl R: Sex differences in autoimmune diseases. Biol Sex Differ 2011;2:1.

13 Dalmau J: Anti-NMDA-receptor encephalitis: case series and analysis of the effects of antibodies. Lancet Neurol 2008;7:1091-8.

14 Dalmau J, Lancaster E, Martinez-Hernandez E, et al. Clinical experience and laboratory investigations in patients with anti-NMDAR encephalitis. Lancet Neurol. 2011;10:63-74.
15 DeLorenzo RJ, Hauser WA, Towne AR, Boggs JG, Pellock JM, Penberthy L, Garnett L, Fortner CA, Ko D: A prospective, population-based epidemiologic study of status epilepticus in Richmond, Virginia. Neurology 1996;46:1029-1035.

16 Rossetti AO, Hurwitz S, Logroscino G, Bromfield EB: Prognosis of status epilepticus: role of aetiology, age, and consciousness impairment at presentation. J Neurol Neurosurg Psychiatry 2006;77:611-615.

17 Prüss H, Dalmau J, Harms L, Höltje M, Ahnert-Hilger G, Borowski K, Stoecker W, Wandinger KP: Retrospective analysis of NMDA receptor antibodies in encephalitis of unknown origin. Neurology 2010;75: 1735-1739.

18 Davies G, Irani SR, Coltart C, Ingle G, Amin Y, Taylor C, Radcliffe J, Hirsch NP, Howard RS, Vincent A, Kullmann DM: Anti-Nmethyl-D-aspartate receptor antibodies: a potentially treatable cause of encephalitis in the intensive care unit. Crit Care Med 2010; 38:679-682. 